\title{
Primary Culture of the Freshly Isolated Liver Cells of the Eel
}

\author{
Seiichi HAYASH* and Zentaro OOSHIRO* \\ (Accepted September 14, 1984)
}

\begin{abstract}
The primary culture of the freshly isolated liver cells of the eel was carried out. The isolated cells could attach, spread and form monolayer only on the dish which was coated with fibronectin. The cell number decreased during the culture and decreased by about 40 to $50 \%$ of the initial cell number after 7 days culture. The rate of protein synthesis increased during 8 days culture and the synthesis of the intracellular proteins was always higher than that of the extracellular proteins during the same period. From the investigation of synthesis of the extracellular proteins by fuorography a few proteins were synthesized and excreted by cultured hepatocytes, but the synthesis of the proteins corresponding to the bovine serum albumin was not observed.

From the comparison of glucose, glycogen, and protein synthesis in the freshly isolated and cultured cells, it was found that the cultured cells had higher activity of glycogen and protein synthesis than the isolated cells. The rate of protein synthesis in the cultured cells was 10 to 100 times higher than that in the isolated cells. However, the rate of glucose synthesis in the freshly isolated liver cells was higher than that of the cultured cells.
\end{abstract}

Recently primary cultured hepatocytes have been used to study many kinds of functions of liver; the metabolism of carbohydrates ${ }^{1)}$ and amino acids, ${ }^{2)}$ the biosynthesis and secretion of serum proteins, ${ }^{3,4}$ ) the mechanism of hormonal action, ${ }^{5,8)}$ and pharmacological action of drugs ${ }^{7,8)}$ so on. The availability of primary cultured hepatocytes as experimental system is due to very simple system. Furthermore, primary cultured hepatocytes are more intact than freshly isolated liver cells. ${ }^{3)}$ The abnormal permeability of ions and amino acids and the low ability of protein synthesis were observed in the latter cells. ${ }^{3)}$

Although there are reports of culture of rat, mouse, ${ }^{10)}$ and chicken ${ }^{4)}$ liver cells, all their methods are primary culture of hepatocytes forming monolayer in a dish. When hepatocytes are cultured, some factors to attach, spread, and grow are needed. Usually these factors are included in serum as minor components. ${ }^{11}$ ) The number of cells cultured by these method can not be increased by cell division and the cells can not servive more than 10 to 15 days. ${ }^{3)}$

We investigated gluconeogenesis by using the freshly isolated liver cells of the eel. ${ }^{12,13)}$ As described above, since there are some incompleteness in the freshly isolated liver cells the primary culture of hepatocytes of the eel was carried out. This report describs the method of the primary culture of the freshly isolated liver cells of the eel and the synthesis of glucose, glycogen, and protein by cultured cells.

\section{Materials and Methods}

\section{Materials}

Williams' E medium (WE), NU-serum, and horse serum were obtained from Flow Laboratories, Inc., Collaborative Research, Inc., and Givco Laboratories, Inc., respectively. L-[U- $\left.{ }^{14} \mathrm{C}\right]$ Lactate, [U- $\left.{ }^{14} \mathrm{C}\right]$-pyruvate, D-[U- $\left.{ }^{14} \mathrm{C}\right]$-glucose, and L-[U-14 C]-leucine were purchased from Radiochemical Centre, Amersham. Plastic dishes for cell culture were obtained from Falcon Labware, Inc. Collagenase ( $\mathrm{Cl}$. histoliticum) and collagen were obtained from Wako Pure Chemical Industries, Ltd. and Koken, Ltd., respectively. Fuji X-ray film RX was purchased from Fuji Film, Ltd. 1,4-Bis[2-(4-methyl-5-phenyloxazolyl)] benzene (dimethyl-POPOP) and 2,5-diphenyloxazole (PPO) were purchased from Nakarai Chemicals, Ltd. Bio-Gel A $15 \mathrm{~m}$, ion-exchange resins of AG $1 \times 8$ and AG $50 \times 8$, and Bio-Rad Protein Assay Kit were purchased from Bio-Rad Laboratories, Inc.

Eels

Japanese cultured eels Anguilla japonica weighing

* Faculty of Fisheries, Kagoshima University, Shimoarata 4-50-20, Kagoshima 890, Japan (林征一 ・大 城善太郎：鹿胃息大学水産学部). 
about $200 \mathrm{~g}$ were purchased from Sueyoshi Co. in Kagoshima city. They were kept in freshwater aquaria and fasted for about one week before use.

\section{Primary Culture}

Livers were excised from anesthetized eels and perfused with $\mathrm{Ca}^{++}$-free modified KREBS-RINGER bicarbonate buffer ( $\mathrm{pH} 7.4$ ) containing collagenase $(15 \mathrm{mg} / 50 \mathrm{ml})$ at room temperature for $30 \mathrm{~min}$. RINGER solution was consisted of $120 \mathrm{mM} \mathrm{NaCl}$, $4.7 \mathrm{~mm} \mathrm{KCl}, 2.4 \mathrm{mM} \mathrm{CaCl}, 1.25 \mathrm{mM} \mathrm{MgSO}_{4}$, $1.25 \mathrm{mM} \mathrm{KH}_{2} \mathrm{PO}_{4}$, and $23 \mathrm{~mm} \mathrm{NaHCO}$ and gassed with $95 \% \mathrm{O}_{2} / 5 \% \mathrm{CO}_{2}$. Then they were purfused with $\mathrm{Ca}^{++}$, $\mathrm{Mg}^{++}$-free RINGER solution containing 2 mM EDTA by non-recirculating system. The liver was removed from the perfusing apparatus into a beaker, in which $\mathrm{Ca}^{++}, \mathrm{Mg}^{++}$-free RINGER solution containing $2 \mathrm{~mm}$ EDTA was added. The liver was minced with scissors in icebath. The minced liver was filtered with nylon gauge into a centrifuging tube and the filtrate was centrifuged at $50 \times \mathrm{g}$ for $1.5 \mathrm{~min}$. The supernatant was removed with Pasteur pipett gently. Precipitated cells were suspended with RINGER solution and centrifuged again. This procedures were repeated three times. Finally the cells precipitated were suspended in a small volume of RINGER solution. All these procedures were done according to the method described previously ${ }^{14)}$ except that sterilized apparatuses and RINGER solution were used.

Cell density of cell suspension was measured by blood counter before seeding cells to a dish. Isolated cells were seeded at the density of 2 to $4 \times 10^{s}$ cells $/ \mathrm{cm}^{2}$ into a plastic dish. The medium for culture was WilliaMs' E medium (WE) containing $23 \mathrm{~mm} \mathrm{NaHCO}$ and $10 \% \mathrm{NU}_{3}$-serum. The incubation for the culture was performed at $30^{\circ} \mathrm{C}$ under $5 \% \mathrm{CO}_{2} / 95 \%$ air. All dishes were coated with the fibronectin $\left(2.5-5 \mu \mathrm{g} / \mathrm{cm}^{2}\right)$ isolated from horse serum before isolated cells were seeded. The half of the medium was changed after the first 1 to 2 days of culture and then the whole medium was changed once every 2 days.

\section{Measurement of Cell Number of Cultured Hepato- cytes}

Medium was aspirated from the dish of cultured hepatocytes and the dish was rinsed twice with $2 \mathrm{~m} l$ of $0.05 \%$ trypsin in $0.01 \mathrm{M}$ phosphate buffer (pH 7.4)-0.15 M NaCl-1 mM EDTA (phosphate buffer saline). One $\mathrm{m} l$ of $0.05 \%$ trypsin-phosphate buffer saline was added to the dish and the dish was incubated at $30^{\circ} \mathrm{C}$ in $\mathrm{CO}_{2}$ incubator for 10 min. After the incubation the solution in the dish was pipetted vigorously and then the cell number of the suspension obtained was counted by blood counter.

\section{Preparation of Fibronectin}

The fibronectin was prepared from horse serum by using gelatin-agarose gel. Bio-Gel A $15 \mathrm{~m}$ was activated with $\mathrm{CNBr}$ by the method of MARCH et $a l{ }^{13)}$ and then $125 \mathrm{ml}$ of $0.2 \mathrm{M} \mathrm{NaHCO}_{3}$ (pH 9.5) containing $2 \mathrm{~g}$ of gelatin was added to $125 \mathrm{~m} l$ of Bio-Gel activated. The mixture was stirred with propellor at the cold room $\left(7^{\circ} \mathrm{C}\right)$ for $24 \mathrm{~h}$.

Ethanolamine $(18.4 \mathrm{~g})$ was added to the mixture and the $\mathrm{pH}$ of the mixture was adjusted to $\mathrm{pH} 9.7$ with $\mathrm{HCl}$. Then $0.9 \mathrm{ml}$ of $1 \mathrm{M} \mathrm{NaN}_{3}$ was added and stirred at the cold room for $24 \mathrm{~h}$. The gelatinagarose gel was washed with $500 \mathrm{~m} l$ of $0.1 \mathrm{M}$ acetate buffer (pH 4)-0.5 $\mathrm{M} \mathrm{NaCl}$ and $500 \mathrm{ml}$ of $0.1 \mathrm{M} \mathrm{NaHCO}$ buffer ( $\mathrm{pH} 9.5$ )-0.5 $\mathrm{M} \mathrm{NaCl}$ alternately. This washing procedure was repeated 5 times. After washing with $500 \mathrm{ml}$ of $6 \mathrm{M}$ urea the gelatin-agarose gel was washed with phosphate buffer saline containing $0.25 \mathrm{mM} \mathrm{NaN}_{3}$ and packed into a column.

Horse serum $(300 \mathrm{ml})$ was centrifuged at 4,000 $\times \mathrm{g}$ for $\mathbf{3 0} \mathrm{min}$ and the supernatant was applied on the gelatin-agarose gel column. The column was washed with phosphate buffer saline adequately and then the fibronectin was eluted with $1 \mathrm{M}$ $\mathrm{NaBr}-0.02 \mathrm{M}$ acetate buffer (pH 5). ${ }^{16)}$ The eluted fibronectin was dialyzed against phosphate buffer saline and sterilized with Millipore membrane (pore size, $0.22 \mu \mathrm{m}$ ). The sterilized fibronectin was stocked in the freezer at $-20^{\circ} \mathrm{C}$. The fbronectin isolated was shown in Fig. 1.

\section{Measurement of the Incorporation of ${ }^{14} \mathrm{C}$-Labelled Precursor into Glucose, Glycogen, and Protein}

After the cultured cells were washed twice with $2 \mathrm{~m} l$ of serum-free WE or RINGER solution, $2 \mathrm{ml}$ of serum-free WE or RINGER solution was added. Then 20 or $10 \mu l$ of ${ }^{14} \mathrm{C}$-labelled precursor was added to the incubation medium. ${ }^{14} \mathrm{C}$-Labelled lactate, pyruvate, and glucose were diluted with unlabelled compounds. All their specific activity were $0.025 \mathrm{mCi} / \mathrm{mmol}$ and $20 \mu l$ of these precursors $(0.25 \mu \mathrm{Ci})$ was added to the incubation medium. Ten $\mu l$ of ${ }^{14} \mathrm{C}$-leucine $(330 \mathrm{mCi} / \mathrm{mmol}$, $0.5 \mu \mathrm{Ci}$ ) without dilution was added to the incubation medium. After the incubation at $30^{\circ} \mathrm{C}$ in incubator, the medium was removed to the test 


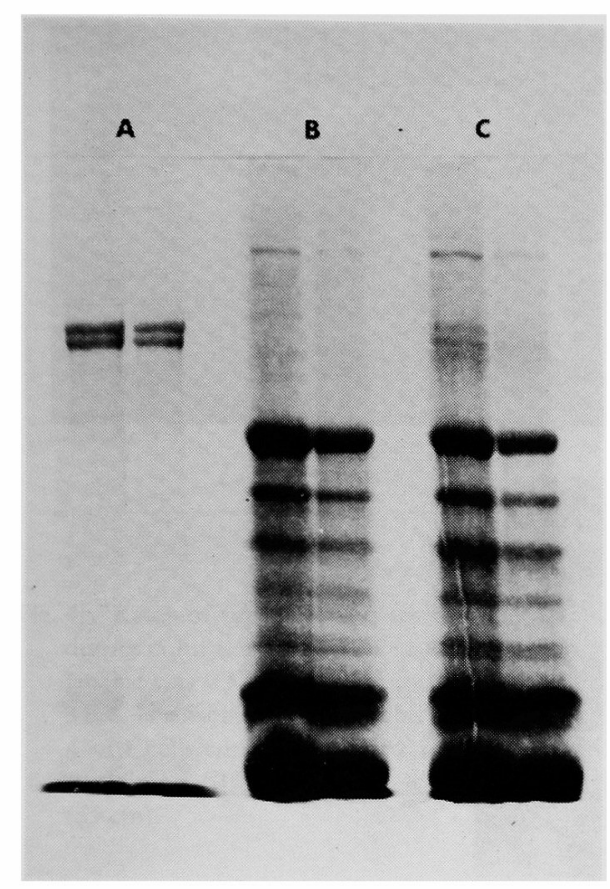

Fig. 1. Fibronectin isolated from horse serum by gelatin-agarose gel column. Electrophoresis was performed by $4 \%$ polyacrylamide- $0.1 \%$ sodiumdodecylsulfate slab gel. A, Fibronectin; B, Horse serum without fibronectin; C, Horse serum.

tube into which $2.5 \mathrm{mg}$ of bovine serum albumin was added previously. One $\mathrm{m} l$ of RINGER solution with which the cultured cells were washed was added to the medium together. Then 0.3 $\mathrm{ml}$ of $60 \%$ perchloric acid (PCA) was added to the combined solution and the mixture was centrifuged at $3,000 \mathrm{rpm}$ for $5 \mathrm{~min}$. The precipitate was suspended with $0.5 \mathrm{ml}$ of $4 \%$ PCA and centrifuged again. This procedures were repeated 3 times. The supernatants were combined and neutralized with $5 \mathrm{~N} \mathrm{KOH}$. The neutralized solution was applied on AG $1 \times 8$ column (formate type, $100-200$ mesh, $\phi 0.7 \times 4 \mathrm{~cm})$ and AG $50 \times 8$ column $\left(\mathrm{H}^{+}\right.$type, $200-400$ mesh, $\left.\phi 0.7 \times 1.5 \mathrm{~cm}\right)$ and ${ }^{14} \mathrm{C}$-glucose fraction was eluted with water as described previously. ${ }^{12)}$ PCA insoluble fraction was dissolved with $1 \mathrm{~m} l$ of $0.1 \mathrm{~N} \mathrm{NaOH}$ and the radioactivity was measured by liquid scintilation counter (Beckman LS-230) as extracellular proteins. On the other hand, to the cultured cells on the dish $2 \mathrm{ml}$ of $5 \%$ trichloroacetic acid (TCA) was added and the cells were scratched with silicon rubber. The scrateched cells and 5\% TCA solution washing the dish were transferred to the

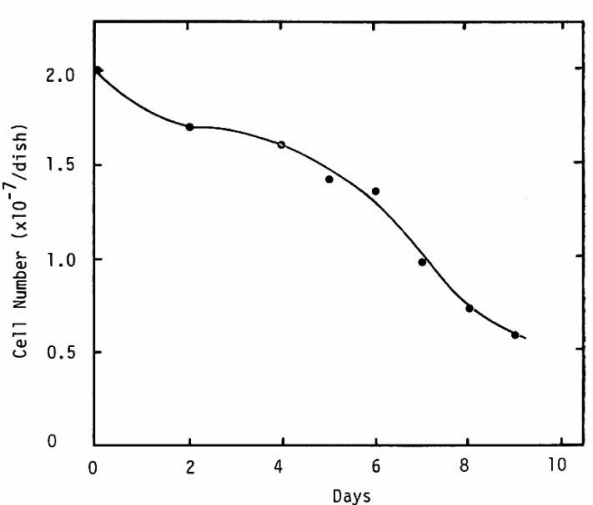

Fig. 2. Changes of cell number of hepatocytes in primary culture. $4 \times 10^{5}$ cells $/ \mathrm{cm}^{2}$ were seeded into $2 \mathrm{ml}$ of WE containing $10 \% \mathrm{NU}$-serum in the plastic dish $(\phi 8 \mathrm{~cm})$. The data are the means of two experiments.

test tube and then the solution was centrifuged. The supernatant was transferred to the test tube containing $300 \mu \mathrm{l}$ of $5 \%$ glycogen. The precipitate was suspended with $5 \%$ TCA and centrifuged. This procedures were repeated 3 times. The supernatants were combined and the equal volume of $95 \%$ ethanol was added. After mixing vigorously the mixture was cooled in ice-bath for $5 \mathrm{~min}$ and then centrifuged. The precipitate of glycogen was washed with $50,95 \%$ ethanol and diethylether. Finally the precipitate was dissolved in $1 \mathrm{ml}$ of water and the radioactivity was measured as glycogen. TCA insoluble fraction was dissolved in $1 \mathrm{ml}$ of $0.1 \mathrm{~N} \mathrm{NaOH}$ and the radioactivity was measured as intracellular proteins.

The same procedures were performed when the freshly isolated cells were used. Protein concentration was determined by dye-binding method using Bio-Rad Protein Assay Kit.

\section{Polyacrylamide Gel Electrophoresis and Fluoro- graphy}

Polyacrylamide gel electrophoresis was performed according to the method of LAEMMLI ${ }^{17}$ ) and fluorography of acrylamide slab gel was done by the method of BONNER and LASKEY. ${ }^{18)}$

\section{Results}

Changes of Cell Number and Microscopic Studies during Culture

The cell number of cultured hepatocytes was measured and as shown in Fig. 2 it was decreased from the first 2 to 3 days of culture. It was de- 


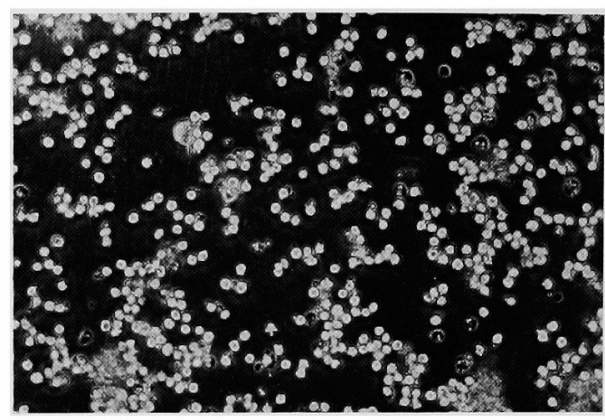

A

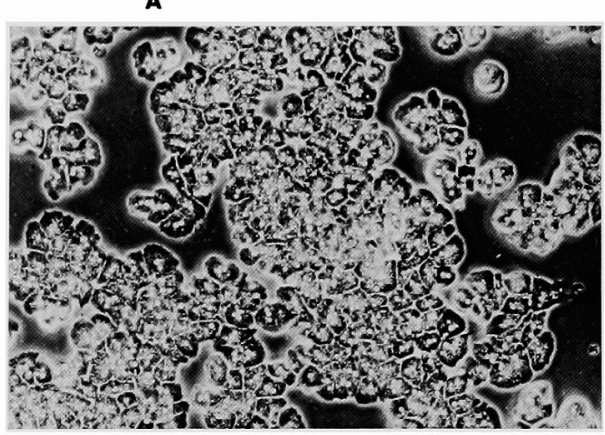

c

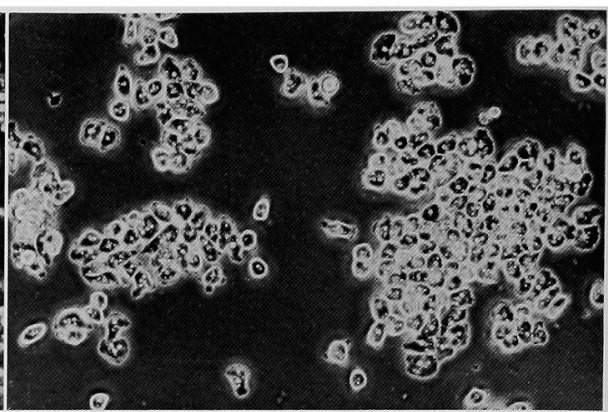

B

Fig. 3. Phase contrast microscopy of freshly isolated and cultured cells. $4 \times 10^{5} \mathrm{cells} / \mathrm{cm}^{2}$ were seeded into WE containing $10 \% \mathrm{NU}$-serum. A-C were cultured on day $0,3,5$, respectively. All magnifications are $\times 93$.

creased to 40 to $50 \%$ of the initial cell number after 7 days culture.

Microscopic studies showed that freshly isolated liver cells being spherical in shape attached to the dish and each cells connected together. Then they became flat during attachment and spreaded to form monolayer (Fig. 3).

When the whole medium in the dish was changed within 2 days culture, the cells attached to the dish were removed from the dish. Therefore we changed the half of the medium after the first 1 to 2 days of culture. The cells after 3 days culture were not removed from the dish by changing the whole medium or washing the cells. However, if the dish was not coated with fibronectin previously before seeding the cells, the attachment of the cells to the dish was incomplete and the cell culture could not be performed. We tried to use the dish coated with collagen, but the attachment of the cell was incomplete and the following culture was impossible.

\section{Protein and Glycogen Synthesis by Cultured Hepatocytes}

The incorporation of ${ }^{14} \mathrm{C}$-leucine into protein increased during the culture of the cells as shown in Fig. 4. The increase in the incorporation continued over 8 days culture. The incorporation into the extracellular proteins was always about one fifth of that into the intracellular proteins during the periods.

Time course of protein and glycogen synthesis in the hepatocytes cultured for 6 days was investigated (Fig. 5). ${ }^{14} \mathrm{C}$-Glucose and ${ }^{14} \mathrm{C}$-leucine were incorporated into glycogen and intracellular proteins linearly during $8 \mathrm{~h}$ of the incubation respectively. The incorporation of both precursors into extracellular proteins was lower than that into intracellular proteins.

Polyacrylamide slab gel electrophoresis of the proteins incorporating ${ }^{14} \mathrm{C}$-leucine was performed and then fluorography of the gel was done (Fig. 6). Electrophoresis of the eel serum proteins was performed at the same time for comparison. The incorporation into $\mathrm{P} 1$ protein was observed in the intracellular proteins as shown in Fig. 6-B. The incorporation of P2 protein was observed in the intra- and extracellular proteins. The protein corresponding bovine serum albumin was recognized in the intracellular proteins stained with 


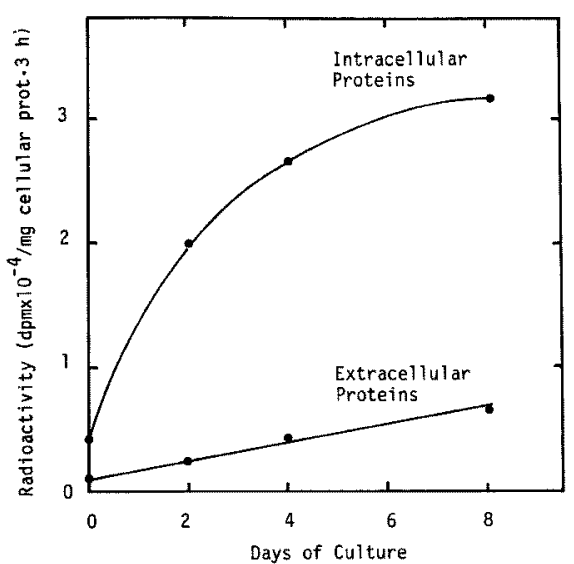

Fig. 4. Rates of synthesis and secretion of proteins during culture. The initial radioactivity of ${ }^{14} \mathrm{C}$ leucine was $0.5 \mu \mathrm{Ci}$ and the incubation time was $3 \mathrm{~h}$. The isolated cells at the initial density of $4 \times 10^{5}$ cells $/ \mathrm{cm}^{2}$ were seeded into $2 \mathrm{ml}$ of WE containing $10 \% \mathrm{NU}$-serum in the plastic dish $(\phi 5 \mathrm{~cm})$.

coomassie brilliant blue, but ${ }^{14} \mathrm{C}$-leucine was not incorporated into the protein as shown in Fig. 6-A, B. The incorporation into P3 protein was observed in the intracellular proteins but not in the extracellular proteins. P4 protein was observed at the highest density among the eel serum proteins and the incorporation into $\mathrm{P} 4$ protein was observed in the intra- and extracellular proteins.

The Comparison of Glucose, Glycogen, and Protein Synthesis in the Freshly Isolated and Cultured Cells

Table 1 shows glucose, glycogen, and protein synthesis in the freshly isolated and cultured cells. Almost no glycogen synthesis in the freshly isolated liver cells was observed, whereas that of the cultured cells was observed. Protein synthesis in the freshly isolated liver cells was from $1 / 10$ to $1 / 100$ of that in the cultured cells. However, glucose synthesis in the isolated liver cells was higher than that of the cultured cells. Especially when serum-free WE medium was used as the incubation medium, glucose synthesis in the isolated liver cells was from 3 to 8 times higher than that in the cultured cells.

\section{Discussion}

When the freshly isolated liver cells of the eel were cultured, the difficulty of the attachment of

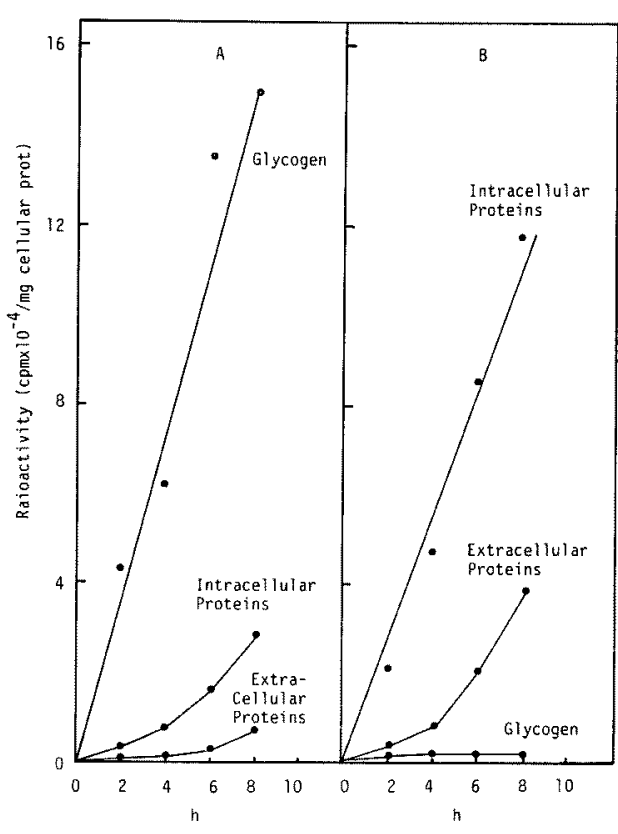

Fig. 5. Time course of protein and glycogen synthesis by cells cultured for 6 days. The initial radioactivity of ${ }^{14} \mathrm{C}$-glucose (A) and ${ }^{14} \mathrm{C}$-leucine (B) were 0.25 and $0.5 \mu \mathrm{Ci}$ respectively. Culture conditions were similar to those for Fig. 4 .

the cells to a dish was most remarkable difference from the culture of rat or mouse hepatocytes. In the culture of rat hepatocytes the attachment of the cells to a dish was usually attained by using the medium containing $10 \%$ fetal bovine serum and the following culture including spreading to form monolayer was performed. It was reported that insulin and dexamethazone stimulated the attachment of the cells. ${ }^{3)}$ However, in the culture of the eel hepatocytes the attachment to a dish was incomplete and the spreading of the cells was not observed even if the medium containing insulin and dexamethasone was used. The cell culture of the eel liver was possible only when the dish coating with fibronectin was used. The dish coated by collagen was also tried to attach the cells. However, the attachment of the cells was incomplete and the following culture was impossible. It is revealed that the role of serum is to attach and maintain the cells and the attachment of the cells is due to the fibronectin in serum. ${ }^{12}$ For the attachment of hepatocytes of the eel, however, the quantity of the fibronectin in serum seemed to be incomplete. It is also suggested that the incom- 


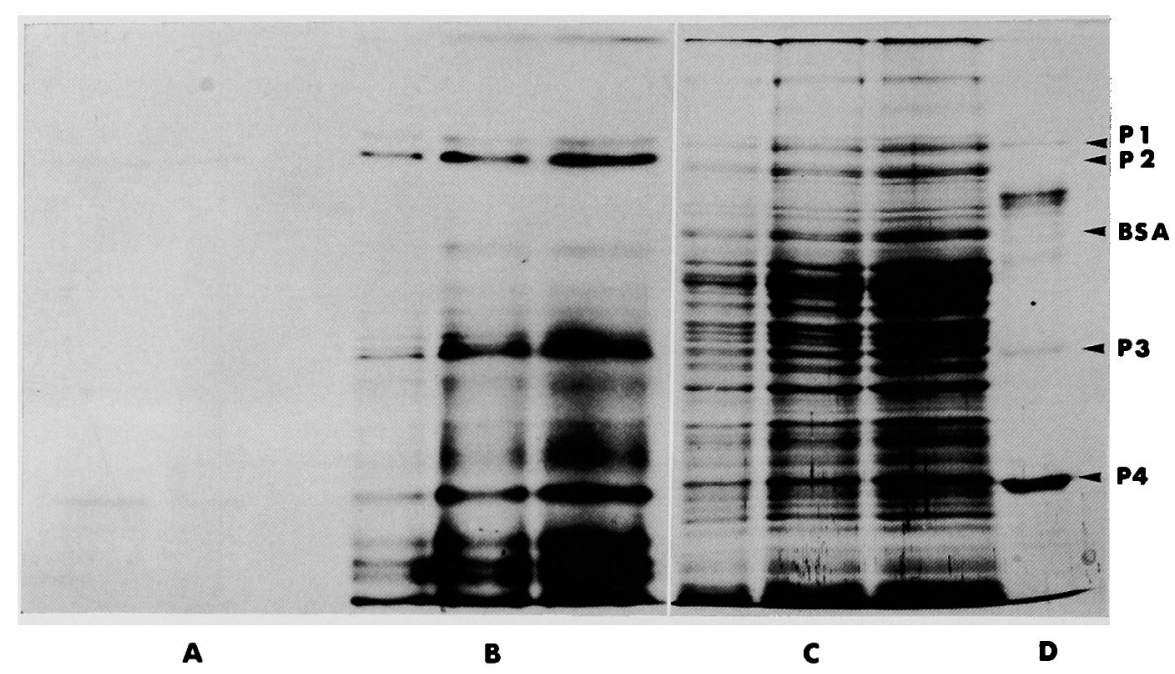

Fig. 6. Fluorogram of a sodiumdodecylsulfate-10\% polyacrylamide slab gel resolving the extraand intra-cellular proteins of cells in primary culture. Cells cultured for 8 days were used. The initial radioactivity of ${ }^{14} \mathrm{C}$-leucine was $0.5 \mu \mathrm{Ci}$ and the incubation time was $3 \mathrm{~h}$. Culture conditions were similar to those for Fig. 4. Fluorogram of extra- and intra-cellular proteins respectively; $\mathbf{C}, \mathbf{D}$, Intracellular and the eel serum proteins stained with coomassie brilliant blue respectively.

Table 1. The comparison of glucose, glycogen, and protein synthesis in the freshly isolated and cultured cells. The initial concentration of substrates was $5 \mathrm{~mm}$ except the concentration of glucose in WE medium, which was $15 \mathrm{mM}$. The initial radioactivity of substrates was 0.25 $\mu \mathrm{Ci}$. Cells for 5 days culture were used and culture conditions were similar to those for Fig. 4 . The data for the isolated cells are the means \pm S.E. of three experiments and the data for the cultured cells are the means of two experiment

\begin{tabular}{|c|c|c|c|c|c|c|c|}
\hline Cells & Substrate & $(\mathrm{mm})$ & Medium & $\begin{array}{l}\text { Protein } \\
\text { (mg) }\end{array}$ & $\begin{array}{c}\text { Glucose } \\
(\mathrm{cpm} / \mathrm{mg} \cdot \mathrm{h})\end{array}$ & $\begin{array}{c}\text { Glycogen } \\
(\mathrm{cpm} / \mathrm{mg} \cdot \mathrm{h})\end{array}$ & $\begin{array}{c}\text { Protein } \\
(\mathrm{cpm} / \mathrm{mg} \cdot \mathrm{h})\end{array}$ \\
\hline \multirow[t]{6}{*}{ Isolated Cells } & ${ }^{14} \mathrm{C}$-Lactate & $(5)$ & RINGER & $5.3 \pm 0.2$ & $5790 \pm 95$ & 0 & $89 \pm 4$ \\
\hline & & ( 5$)$ & WE & $5.7 \pm 0.2$ & $2649 \pm 26$ & 0 & $67 \pm 5$ \\
\hline & ${ }^{14} \mathrm{C}$-Pyruvate & ( 5$)$ & RINGER & $6.0 \pm 0.3$ & $4770 \pm 27$ & $3 \pm 2$ & $135 \pm 9$ \\
\hline & & ( 5$)$ & WE & $6.6 \pm 0.2$ & $2333 \pm 17$ & $7 \pm 3$ & $92 \pm 4$ \\
\hline & ${ }^{14} \mathrm{C}$-Glucose & (5) & RINGER & $4.8 \pm 0.7$ & & $10 \pm 2$ & $59 \pm 18$ \\
\hline & & (15) & WE & $5.4 \pm 0.7$ & & $8 \pm 2$ & $13 \pm 2$ \\
\hline \multirow[t]{6}{*}{ Cultured Cells } & ${ }^{14} \mathrm{C}$-Lactate & ( 5$)$ & RINGER & 4.0 & 1730 & 48 & 1220 \\
\hline & & ( 5$)$ & WE & 4.4 & 360 & 254 & 2470 \\
\hline & ${ }^{14} \mathrm{C}$-Pyruvate & ( 5$)$ & RINGER & 4.1 & 2510 & 60 & 2200 \\
\hline & & (5) & WE & 3.8 & 880 & 736 & 5300 \\
\hline & ${ }^{14} \mathrm{C}$-Glucose & ( 5$)$ & RINGER & 4.0 & & 308 & 530 \\
\hline & & (15) & WE & 4.0 & & 3017 & 530 \\
\hline
\end{tabular}

pleteness of the attachment is due to the damage of cytoplasmic membrane during the preparation of isolated liver cells or to different structure of the cell surface carbohydrate chains of the eel liver.

Cell number of cultured cells was decreased during 8 days culture. It is assumed that the cell division during the culture did not occured as the cultured cells of rat liver did not. ${ }^{3)}$ Although the liver can regenerate in vivo, the cultured hepatocytes can not increase by cell division. The reason is still uncertain, but there are some reports on DNA synthesis and mitosis of hepatocytes in primary culture. ${ }^{10,20)}$ It was reported that arachidonic acid stimulated DNA synthesis and mitosis 
of neonatal rat hepatocytes in primary culture. ${ }^{19)}$

The synthesis of the intracellular proteins by the eel liver cells in primary culture was always higher than that of the extracellular proteins during 8 days culture (Fig. 4). This fact was the same even if the incubation time of the incorporation of ${ }^{14} \mathrm{C}$ leucine was changed to more longer periods as shown in Fig. 5. These results were quite different from the protein synthesis by cultured rat hepatocytes. In cultured rat hepatocytes the incorporation into extracellular proteins was higher than that into intracellular proteins. ${ }^{3}$ Certainly the extracellular proteins of the eel hepatocytes recognized by fluorography were a few kinds of proteins and the incorporation into the protein corresponding bovine serum albumin was not observed in the extra- and intra-cellular proteins of the eel hepatocytes in primary culture. This assumes that the material(s) to stimulate synthesis and secretion of serum proteins still lacked in the culture medium. It is also needed to investigate serum proteins of fishes.

From the comparison of the synthetic ability in the freshly isolated and cultured cells of the eel liver it was found that protein synthesis by the freshly isolated liver cells was remarkably lower than that by the cultured cells. As it was reported that the low protein synthesis in the freshly isolated liver cells of rat was due to the disaggregation of polysome, ${ }^{3)}$ in the eel liver cells the same reason seemed to lower protein synthesis. Almost no glycogen synthesis was observed in the freshly isolated liver cells of the eel. This suggests that the activity of glycogen synthetase was repressed and the activity of phosphorylase was stimulated. However, if RINGER solution was used as the incubation medium, glycogen synthesis became low even in the cultured hepatocytes as shown in Table 1.

Glucose synthesis in the freshly isolated liver cells of the eel was higher than that of the cultured hepatocytes. It is well known that the energy corresponding 6 moles of ATP is needed to synthesize one mole of glucose from lactate or pyruvate. Furthermore, glucose is synthesized through the pathway which involves both the mitochondrial and cytoplasmic fractions. Therefore the energy producing system and mitochondria in the freshly isolated liver cells as well as in the cultured hepatocytes of the eel seem to have normal functions. The reason that glucose synthesis in the isolated liver cells was higher than that in the cultured hepatocytes seems that the former cells are influenced by previous conditions of the eel, such as starvation and hormonal state.

This work was supported in part by a Grant-inAid for Scientific Research (56360017 and 59560206) from the Ministry of Education.

\section{References}

1) I. Probst, P. Schwartz, and K. Jungermann: Eur. J. Biochem., 126, 271-278 (1982).

2) C. Noda, T. Nakamura, and A. Ichihara: $J$. Biol. Chem., 258, 1520-1525 (1983).

3) K. Tanaka, M. Sato, Y. Tomta, and IChiHara: J. Biochem., 84, 937-946 (1978).

4) J. LiAng and G. Grieninger: Proc. Natl. Acad. Sci. USA, 78, 6972-6976 (1981).

5) P. R. Walker and M. J. Grindle: J. Cell. Physiol., 91, 181-192 (1977).

6) T. Nakamura, S. Kato, and A. Ichihara: $J$. Biochem., 95, 1691-1696 (1984).

7) U. Giger and U. A. MEYER: J. Biol. Chem., 256, 11182-11190 (1981).

8) R. J. Gerson and Z. A. Shikh: Biochem. J., 208, 465-472 (1982).

9) K. TANAKA and A. IChiHARa: Protein, Nucleic Acid and Enzyme, 23, 1259-1271 (1978).

10) J. E. Klaunig, P. J. Goldblatt, D. E. Hruton, M. E. Lipsky, and B. F. Trump: In Vitro, 17, 926-934 (1981).

11) Y. Horiuti, T. Nakamura, and A. Ichihara: J. Biochem., 92, 1985-1994 (1982).

12) S. Hayashi and Z. Ooshiro: J. Comp. Physiol, 132, 343-350 (1979).

13) S. Hayashi, Z. Ooshiro, and T. Itakura: Bull. Japan. Soc. Sci. Fish., 48, 1789-1793 (1982).

14) S. HAYASHI and Z. Ooshiro: Bull. Japan. Soc. Sci. Fish., 44, 499-503 (1978).

15) S. C. March, I. Parikn, and P. Cuatrecasas: Anal. Biochem., 60, 149-152 (1974).

16) W. Dessau, B. C. Adelmann, R. Timpl, and G. R. MARTIN: Biochem. J., 169, 55-59 (1978).

17) U. K. LaEmmLI: Nature, 227, 680-685 (1970).

18) W. M. BONNER and R. A. LASKY: Eur. $J$. Biochem., 46, 83-88 (1974).

19) P. G. Andris, J. F. Whitfied, and U. Armato: Exp. Cell. Res., 134, 265-272 (1981).

20) D. L. Freidman, T. H. Claus, S. J. Pilkis, and G. E. Pine: Exp. Cell. Res., 135, 283-290 (1981). 